\title{
THE CANADIAN CRIMINAL JURY: SEARCHING FOR A MIDDLE GROUND
}

\author{
NEIL VIDMAR* \\ I \\ INTRODUCTION
}

In many important respects, the contemporary Canadian criminal jury system may be viewed as a hybrid of the $E$ nglish and A merican jury systems. This statement does not imply a direct A merican influence on the conception of the jury because, as will be discussed below, Canadian judges have often expressly rejected A merican practices, and in the very recent past, tended to defer primarily to England when seeking guidance from case law. N evertheless, on a number of dimensions, Canadian jury law and practice occupies a middle ground between that of these other two countries.

I can begin to make the point clear by describing a Canadian trial, R. v. B ernardo, that overlapped the 0.J. Simpson murder trial in the U nited States. R ecall that Simpson, a former A merican football star and television celebrity, was charged with the vicious knife-slaying of his former wife and a young man just outside his ex-wife's residence. A side from the fact that the Simpson trial involved a famous football player and television celebrity charged with gruesome knife-slayings, there were important trial characteristics that could occur only in some A merican jurisdictions. The preliminary hearing and the entire trial were televised. The prospective jurors were given a lengthy questionnaire that asked about their personal attitudes, beliefs, and lifestyles, and then they were questioned at length in court on their views in a process that took weeks of court time before the jury was chosen. In addition, alternate jurors were selected to sit with the other jurors in the event one or more of the jurors were

Copyright $\odot 1999$ by L aw and Contemporary Problems

This article is also available at http://www.law.duke.edu/journals/62L C PV idmar.

* R ussell M . R obinson II Professor of L aw and Professor of Psychology, D uke U niversity.

I am indebted to Professor David Paciocco for comments on this article and to the Honorable $M$ adam J ustice L ouise Charron, $A$ lan $D$. Gold, and the H onorable J ustice $H$ enry V ogelsong for comments on an earlier article that is incorporated in this article.

1. The case of R. v. B ernardo is unreported. For related litigation, see Thompson Newspapers L td. v. The Q ueen [1994] 121 D.L.R.4th 42 (O nt. C.A.). M y account of the Homolka and Bernardo trials is developed from personal sources as well as media accounts. A reasonable summary of the Bernardo case can be found in the weekly issues of M aclean's magazine from May 15, 1995 through O ctober 16, 1995. M ore detailed accounts of the trial can be found in the Toronto Globe and M ail or Toronto Star newspapers covering that same period. See, e.g., Nick Pron \& J ohn D uncanson, B ernardo Trial Has J ury Pool of 1,500, TORONTO STAR, A pr. 11, 1995, at A 1. O ther discussions of the background of the case and the trial can be found in FRANK DAVEY, KARLA'S WEB: A CULTURAL InVESTIGATION OF THE MAHAFFy-French MURDERS (1994); Stephen WILLIAMS, INVISIBLE DARKNESS: The StRANGE CA SE OF PA Ul BERNARDO AND KARLA HOMOLKA (1996). 
excused for illness or other reasons. The jurors were sequestered for the entire time of the months-long trial. In mid-trial, several jurors were removed and replaced by alternates, on the suspicion that they were planning to sell the story of the jury deliberations to tabloid newspapers or book publishers at the trial's conclusion. Lawyers for the prosecution and defense engaged in media interviews while the trial was in progress.

Simpson's trial captured world-wide attention when it was broadcast over the CNN television network. While in many respects Simpson's trial was an anomaly within the U nited States, ${ }^{2}$ contrasting it with Bernardo is useful because, like the Simpson case, the crimes of which Bernardo was accused were heinous, the case captured the attention of the Canadian public, and it raised serious threats to the integrity of the Canadian legal process. However, the B ernardo case shows some restrictions on media coverage that evokes comparison with E ngland, A ustralia, and New Zealand. I ts jury selection process and trial controls contrast markedly with the $U$ nited States. The case also raises the specter of attempts to control pretrial publicity in any country in an age of international mass media and the internet.

A gainst a backdrop of a series of rapes by the "Scarborough rapist" that terrorized a number of Toronto suburbs beginning in mid-1990, two teenage girls, Linda M ahaffy and K risten French, went missing in 1991 and 1992. Their sexually abused bodies were subsequently found. Mahaffy's body had been dismembered by a power saw, encased in cement, and dumped in a lake. Police were stymied until January 1993, when K arla Homolka, an attractive twentythree year-old woman residing in St. Catherines, O ntario, was severely beaten by her twenty-nine year-old husband, Paul Bernardo. In the police investigation that followed, Homolka confessed that she had participated with B ernardo in the kidnapping, sexual enslavement, and degradation of the two teenagers. $\mathrm{H}$ omolka nevertheless insisted that Bernardo alone murdered the girls. She also eventually implicated Bernardo (and herself) in numerous other sexual crimes, including the drugging and rape of her younger sister, Tammy, that accidentally resulted in the girl's death. The latter incident had to that point been treated as a natural but unexplained death. Finally, she informed the authorities that the rape and torture of $M$ ahaffy and French, each occurring over several days, had been videotaped by B ernardo.

B ernardo was arrested and charged as the Scarborough rapist in February 1993 and later charged with kidnapping, rape, and murder. Canadian and U .S. media covered the story extensively and engaged in much speculation about the crimes, but police and prosecutors remained tight-lipped. A fter many searches of the couple's home over a period of seventy days, police failed to find the videotapes. Thus, Homolka became the Crown's crucial witness against her husband, and a highly controversial plea bargain was struck in M ay 1993. For her full cooperation and testimony, Homolka would receive two twelve-year

2. See Nancy Jean King, The A merican Criminal Jury, 62 LAW \& CONTEMP. PRoBs. 41, 60-61 (Spring 1999). 
sentences for manslaughter to be served concurrently. A t her J une 1993 plea and sentencing trial, the judge allowed Canadian media representatives to be present, but in an attempt to preserve the integrity of the Bernardo trial, he drew upon common law precedent to forbid them from publishing any details until the latter trial was completed.

D espite the reporting ban, public rumors about the $\mathrm{H}$ omolka and Bernardo crimes were intense. $\mathrm{R}$ adio and print media in nearby $\mathrm{B}$ uffalo, $\mathrm{N}$ ew $\mathrm{Y}$ ork, as well as other A merican mass media, reported some of the forbidden information. A public opinion survey in December 1993 found that many persons in the trial venue (moved to Toronto from St. Catherines) reported that they had learned details of the case from other persons, from reading U.S. newspapers, or from facsimile or internet communications. ${ }^{3}$ B ernardo's public trial did not commence until M ay 1995, but in the interim, the case had been kept before the public by litigation over the publication ban, the resignation of Bernardo's first lawyer and the appointment of a new defense team, publicity from various victims' rights groups, widespread dissemination of anonymous flyers reporting erroneous and gruesome details about the $M$ ahaffy and French deaths, media editorials about the Homolka plea bargain, and allegations of police incompetence. ${ }^{4}$ M oreover, rumors surfaced that the missing videotapes had been found and would be used as evidence. These last rumors turned out to be true. ${ }^{5}$

When the trial began in M ay 1995, 980 prospective jurors were summoned to appear at the ballroom of the downtown R oyal $\mathrm{Y}$ ork H otel, which had been turned into a large courtroom. The charges against the accused were readtwo counts each of first-degree murder, kidnapping, unlawful confinement, and aggravated sexual assault, and one count of causing an indignity to a corpse. Bernardo pleaded not guilty to each count. Jury selection began. In order to eliminate persons who believed they could not serve under the trial conditions, A ssociate C hief J ustice Patrick L eSage, the trial judge, explained to the assembled panel that the trial would last for an estimated four months and that the jurors would be required to view very explicit photographs and videos of sexual acts. O ver the next three days, the remaining members of the panel were randomly called one-by-one to a nearby courtroom, placed under oath, and asked up to eight questions in a procedure that Canadian law calls a "challenge for cause." ${ }^{6}$

3. See A ngus R eid Group, Inc., Public O pinion on Publication B ans and the H omolka Trial (D ec. 29, 1993).

4. The editorials involved general discussion of the issues and the need for investigation and thorough public airing of the matter after the Bernardo trial was completed, when the media would be free from the judicial restraint.

5. Bernardo's first lawyer obtained possession of the videotapes from information provided by his client, following the 70-day police search of Bernardo's home. E ventually the tapes were turned over to the prosecution. The investigation into possible obstruction of justice is described in

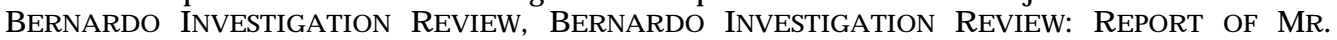
JUSTICE ARCHIE CAMPBELL (1996).

6. For more discussion of the challenge for cause, see infra Part III.B.3. 
The questions asked of the jurors were as follows: ${ }^{7}$ (1) Have you read, heard, or seen anything about this case in the media (newspapers, radio, or television)? (2) Have you obtained information about it from anywhere else? (3) Have you read, heard, or seen anything about the accused's, Paul Bernardo's, background, character, or lifestyle? (4) H ave you read, heard, or seen anything about $\mathrm{K}$ arla Homolka or about her trial? (5) A s a result of this case, some groups and organizations have circulated petitions or have sought support concerning issues which relate to this case, the victims, or their families. Have you supported any of these groups or associations, for example, by signing a petition, writing a letter of support, or by making a donation? (6) A s a result of any knowledge, discussion, and/or contact with any group or organization, have you formed an opinion about the guilt or innocence of the accused, Paul Bernardo? (7) If you have formed an opinion about the guilt or innocence of the accused, are you able to set aside that opinion and decide this case only on the evidence you hear in the courtroom and the judge's directions on the law? (8) A nswer the following question with a yes or no: Is there anything we have not asked you about why you could not judge this case fairly and impartially according to the evidence heard at trial and the judge's directions on the law? Beyond their responses to these questions, no other information about the jurors, other than physical appearance and demeanor in the courtroom, was available to the Crown prosecutor or the defense lawyer.

In contrast to U.S. practice, ${ }^{8}$ the trial judge does not have authority to determine which jurors are impartial and which are not. ${ }^{9} \mathrm{R}$ ather, that decision is placed in the hands of two layperson "triers." For the selection of the first juror, two persons are randomly chosen from the venire panel and sworn to serve as triers. ${ }^{10}$ They listen to the prospective jurors' answers to the questions and, under instructions from the judge, render a verdict on whether he or she is "impartial between the Q ueen and the accused." If a prospective juror is found to be not impartial, another is called, and the process continues until an unbiased juror is found. A fter the first juror is chosen, he or she replaces one of the

7. See Excerpts from R. v. Bernardo, in JURY TRIALS (National J udicial Institute, Nov. 27-29, 1995).

8. Seenancy Gertner \& Judith H. MiZner, The LA W Of JuRIES 2-3 (1997).

9. Throughout the rest of this article, I will sometimes be sparse with citations to specific authority and procedures. The interested reader should consult the following sources for details: E.G. Ewaschuk, Criminal Pleadings \& Practice in Canada (2d ed. 1998); Christopher GRANGER, THE CRIMINAL JURY TRIAL IN CANADA (2d ed. 1996); THE MEDIA, THE COURTS AND THE ChARTER (Philip A nisman \& Allen M. Linden eds., 1986); A LAN W. MEWETT, A INTRO-

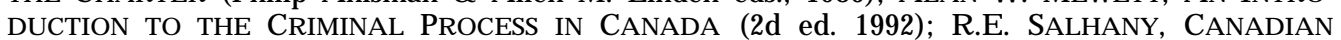
CRIMINAL PROCEDURE (6th ed. 1998); DA VID M. TANOVICH ET AL., JURY SELECTION IN CRIMINAL TRIALS (1997).

10. For a description of challenge for cause in another case and an assessment of its effectiveness, see N eil V idmar \& Julius M elnitzer, J uror Prejudice: A n E mpirical Study of a Challenge for Cause, 22 OSG OODE HALL L.J . 487 (1984). The history of this procedure in Canada has not been explored, but it undoubtedly comes directly from English law. See 3 W ILLIAM BLA CKSTONE, COMMENTARIES *363; J A MES KenNEDY, LA W A ND PRA CTICE OF J URIES 90 (1826); see also Nancy J. King, Silencing Nullification A dvocacy Inside the J ury Room and Outside the Courtroom, 65 U. CHI. L. REV. 433 (1998) (documenting the existence of triers in colonial and post-colonial A merica). 
triers to choose the second impartial juror. The first two jurors then serve as triers for juror number three; jurors two and three are the triers for juror four; the rotating "trier" schedule continues until twelve jurors are seated. ${ }^{11} \mathrm{How}$ ever, even if the triers decide that a person is impartial, either the Crown or the defendant can exercise one of their peremptory challenges-twenty are provided for each side in a murder case- necessitating other jurors to be called and tried until that juror slot is filled. If a juror is acceptable to both sides, he or she is seated in the jury box for the remainder of the proceeding. When the twelfth juror is chosen, the jury is sworn.

With some persons excused for hardship, others excused for bias, and others rejected through peremptory challenges exercised by the prosecution and the defense, 225 veniremen were called in the Bernardo case before a jury was seated. There were no alternate jurors. The total jury selection process took five days, an extraordinarily lengthy proceeding for a Canadian trial. When all twelve were selected, the judge admonished the jurors not to discuss the case with anyone, told them that a number of legal matters still had to be resolved, and ordered them to return in two and a half weeks for the commencement of the trial.

A t the end of May, the trial began with television and print coverage that was unprecedented in Canadian history. A Ithough radio and television were not allowed in the courtroom, the streets outside were jammed with communications equipment. Long queues of spectators waited for the limited public seating. The trial involved some of the most disturbing evidence ever heard and seen in a Canadian courtroom. G raphic videotapes of the rapes and torture of the two girls were played over and over and over for the jury. The press and public were allowed to hear the audio portion of the days and hours of the victims' torture and humiliation by Bernardo and Homolka, but only the jury and court officials saw, as well as heard, the evidence. N evertheless, the audio portion, as well as Karla Homolka's testimony, left little for the imagination, and the print media reported it extensively. Throughout the trial, the jurors went, unescorted, back to their homes each evening. They were not sequestered until they began their deliberations some four months after the trial began. Paul B ernardo was found guilty of the murders and other charges and sentenced to life in prison. ${ }^{12}$ We will likely never learn how the jurors reached their verdict because Canadian law forbids jurors to ever disclose anything about their deliberations.

11. O ne consequence of this unique procedure, of course, is that to a considerable degree the members of the jury are responsible for its make-up. I do not propose to explore the implications of this self-selection process for group cohesion in this article, but draw the matter to the reader's attention. A nother consequence is that through taking part in, as well as observing, the challenge process, the jurors are further educated about the importance of being impartial.

12. Canada permanently abolished capital punishment in 1976 after a 14-year moratorium on hanging. See GRANGER, supra note 9, at 331. Under the life sentence, Bernardo would be eligible to apply for parole after 25 years. H owever, in a subsequent proceeding initiated by the Crown, he was found to be a dangerous offender and is now serving an indefinite life sentence, although that indefinite sentence is subject to periodic review. 
B efore elaborating on the law and rationale behind the procedures involved in the Bernardo trial, let us consider the history of the Canadian jury and develop a profile of the Canadian jury today. ${ }^{13}$

\section{PROFILE OF THE CANADIAN CRIMINAL JURY} A. The H istory of the R ight to J ury Trial in Canada and the Scope of That
Right

English common law, including the right to trial by jury, was followed almost from the beginning of the development of the separate English colonies that eventually became the nation of Canada. For example, N ova Scotia recognized the right to jury trial in 1758 and, following the defeat of the French army on the Plains of A braham outside Q uebec City, the law of E ngland was established in the colony of Q uebec in 1763. A Ithough French civil law was restored in Quebec in 1774, English criminal law remained in force. U nder the $B$ ritish N orth A merica A ct, which established the D ominion of Canada in 1867, the federal Parliament was granted jurisdiction over criminal law, but the provinces maintained certain rights over the administration of that law. In 1892, Parliament passed the Criminal Code that recognized the right to jury trial for serious offenses. When the Constitution A ct, known as the Canadian Charter of R ights and Freedoms ("Charter"), was passed in 1982, it specifically recognized the right to jury trial: "A ny person charged with an offense has the right ... except in the case of an offense under military law tried before a military tribunal, to the benefit of trial by jury where the maximum penalty for the offense is imprisonment for five years or a more severe punishment . . .."14

A Ithough the right to jury trial is enshrined in the Charter, it needs to be understood in the context of the Criminal Code. ${ }^{15}$ When it passed the uniform Criminal Code of 1892, Parliament followed Sir James Fitzjames Stevens's draft English code of $1879,{ }^{16}$ and its basic structure is retained in the modern Criminal Code. ${ }^{17}$ The Code divides offenses into three types. ${ }^{18}$ Indictable offenses include the most serious crimes, such as murder and treason. Murder and treason must be tried in a superior court before a judge and jury. Summary conviction offenses are less serious offenses, such as driving while disqualified, keeping a common bawdy house, and theft or fraud under $\$ 5,000$. These offenses involve maximum punishments of no more than two years in jail (the

13. For general discussion on the origins of trial by jury in criminal cases in E ngland and Canada, see GRANGER, supra note 9, at 11, 26. See also generally DESM OND H. BROWN, THE GENESIS OF THE CANADIAN CRIMINAL CODE OF 1892 (1989).

14. CAN. CONST. (Constitution A ct, 1982) pt. I (Canadian Charter of Rights and Freedoms), $\S 11(f)$ [hereinafter Charter].

15. Criminal Code, R.S.C., ch. C-46 (1985) (Can.).

16. See generally BROWN, supra note 13 .

17. See GRANGER, supra note 9 , at 36 .

18. Seeid. at 37-54. 
typical maximum for a summary offense is six months in jail) and a fine less than $\$ 5,000$. Summary offenses are tried by judge alone in a lower court, and there is no right to jury trial. The third category involves hybrid offenses that can be tried either as an indictable crime or as a summary conviction offense. O ffenses falling under this category include assaults of all kinds, serious fraud, conspiracy, being an accessory to a crime, and drug offenses. The decision to proceed by indictment is solely determined by the Crown A ttorney, that is, the public prosecutor, and, with a few exceptions, is not subject to judicial review. However, once the Crown has elected to proceed by indictment, the accused person has the right to decide whether to be tried by judge and jury or by judge alone for most offenses. ${ }^{19}$

Canada has two official languages, English and French. Section 530 of the Code provides that an accused has the right to be tried by a judge and jury who speak the language of the accused, or, if special circumstances warrant it, a judge and jury composed of persons who speak both languages. ${ }^{20}$ Section 531 provides that a change of venue to a different territory within a province may be made in order to obtain a jury with the required language skills. ${ }^{21}$

It is difficult to obtain nationwide statistics on the absolute number of criminal jury trials or what percentage of accused persons elect for jury trial when they have that option. However, in 1993 in O ntario, the largest province, with a population of eleven million persons (approximately one-third of Canada's entire population), there were 1,018 criminal jury trials in the General Division Court, a superior court. ${ }^{22}$ In contrast, there were 1,368 nonjury trials. Some of the jury trials involved murder or other offenses that are required to be tried by judge and jury. E ven discounting these cases involving no option regarding the choice of factfinder, more accused persons who pleaded not guilty elected for trial by judge alone than trial by jury. When summary conviction offenses are taken into account, the vast bulk of criminal cases, at least ninety percent, are tried by judge alone. ${ }^{23}$ Nevertheless, the institution of the criminal jury continues to occupy an important place in Canadian law.

\section{B. The Structure and Composition of the J ury and Its V erdict}

The Canadian jury is always composed of twelve persons. ${ }^{24}$ No provision is made for alternate jurors and removal of a juror is considered to be a very serious matter. However, a juror can be discharged if he or she becomes ill at any time during the course of the trial, or there is some other "reasonable cause" to discharge a juror. The judge is also vested with the power to declare a mistrial.

19. H owever, a few offenses are not eligible for jury trial. See Criminal Code, supra note 15, $\S \S 469,553$.

20. Seeid. $\S 530$.

21. Seeid. § 531 .

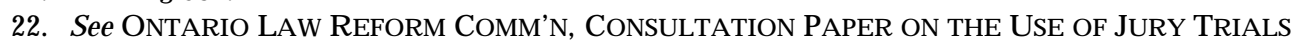
IN CIVIL CA SES 6-7 (1994).

23. This statement is based on personal communications with Professor $D$ avid Paciocco.

24. See Criminal Code, R.S.C., ch. C-46, § 631(5) (1985) (Can.). 
The judge may continue the trial as long as ten jurors remain. ${ }^{25}$ Conviction of an accused by a jury of ten or eleven members has been held to be constitutional under the Charter. ${ }^{26}$

Verdicts must always be unanimous. ${ }^{27}$ There is no provision, as in E ngland and $W$ ales and some A merican states, for a majority verdict. ${ }^{28}$ The judge has the discretion to poll the jury if there is any doubt that the verdict is not unanimous. If the jury has difficulty in reaching unanimity, the judge may provide some guidance on reasonable doubt, but a strong charge to reach unanimity would be considered improper. If the judge concludes that further deliberation would be hopeless, the jury may be discharged and a new trial ordered. ${ }^{29}$

The form of the verdict is ordinarily a general verdict of guilty or not guilty. The Criminal Code provides two exceptions. ${ }^{30}$ The first involves cases of defamatory libel where the judge may provide the jury a special verdict. The second involves instances of what used to be called the insanity defense but is now called a "defense of mental disorder." 31 If a jury decides that the accused committed the act but was suffering from a mental disorder that exempts her from criminal responsibility, it may render such a verdict. In many cases, the jury also has the option of returning a verdict finding the accused guilty of a lesserincluded offense. ${ }^{32}$

Sentencing the accused is the responsibility of the judge, not the jury. ${ }^{33}$ In 1976, Canada abolished the death penalty and substituted a mandatory life sentence with no eligibility for parole for twenty-five years upon conviction of first-degree murder, so jury recommendations are moot on this matter. ${ }^{34} \mathrm{H}$ owever, in instances where an accused who is under the age of eighteen has been found guilty of first- or second-degree murder, or an accused who is over the age of eighteen at the time of the offense is found guilty of second-degree murder, the judge must then tell the jury about the possible statutory range of the sentence and ask if it wishes to make a recommendation. ${ }^{35}$ In the instance of an

\footnotetext{
25. Seeid. § 644; see also GRA NGER, supra note 9, at 190-98 (discussing the discharge of jurors).

26. See GRANGER, supra note 9, at 197-98.

27. Seeid. at 281.

28. See Sally L loyd-B ostock \& Cheryl Thomas, D ecline of the "L ittle Parliament": J uries and J ury Reform in England and Wales, 62 LA W \& CONTEMP. PROBS. 7, 36-37 (Spring 1999); King, supra note 2 , at 46 .

29. See GRANGER, supra note 9 , at 331 .

30. See Criminal Code, R.S.C., ch. C-46, §§ 16, 317 (1985) (Can.). There appears to be no rule against special verdicts, but they are only used in cases that fall within these two exceptions.

31. Seeid. § 16(1).

32. Seeid. $§ 317$.

33. See GRANGER, supra note 9 , at 331 .

34. H owever, after 15 years of a life sentence have been served, a convicted person may apply for judicial review of the sentence. If the Chief J ustice of the province in which the conviction took place decides a review is merited, a jury may be empanelled to hear the application and consider a reduction in the sentence. Two-thirds of the jury must agree for the sentence to be reduced. See Criminal Code, R.S.C., ch. C-46, §§ 745.6-745.64 (1985) (Can.); see also DAVID WATT \& MICHELLE K. FueRST, TREMEEAR'S CRIMINA L CODE 1195-1201 (commenting on these code sections).

35. See Criminal Code, R.S.C., ch. C-46, $\S 745$ (1985) (Can.); see also GRANGER, supra note 9, at 331-32 (commenting on this section); W A TT \& FUERST, supra note 34, at 1189-95 (same).
} 
adult found guilty of second-degree murder, for example, the judge must tell the jury that the accused would ordinarily be eligible for parole after a mandatory ten-year imprisonment and ask the jury if it wants to make a recommendation as to the number of years between ten and twenty-five that the accused should serve before being eligible for parole. The jury does not have to make a recommendation, and any such recommendation is not binding on the judge. The Criminal Code is silent on whether the jury can be informed as to the possible sentence before the jury has reached a verdict in the case, but case law has established that it is legal error to inform the jury about possible punishment prior to its verdict on guilt for any charge, including second-degree murder. ${ }^{36}$ Several provincial courts have ruled that the recommendation does not have to be unanimous. ${ }^{37}$ Finally, the jury's power to decide guilt can be removed if, at the end of the prosecution's case, the judge decides that the Crown has not produced a prima facie case for guilt. In such an instance, the judge will enter a directed verdict of not guilty. ${ }^{38}$

A Ithough not too many years ago the typical Canadian jury consisted primarily of white males selected by the local sheriff, the jury has become much more representative of the population. The selection of the jury list is controlled by provincial statute, and the general rule in the provinces is that the list is compiled by random selection from the electoral rolls in the province or local community. ${ }^{39}$ Litigation based on an unrepresentative jury pool is sparse. While the prosecution or defense may challenge the whole jury array at the start of the trial on the grounds of fraud, partiality, or misconduct, such challenges have been infrequent. ${ }^{40}$ In R. V. Catizone $e^{41}$ and R. v. Nepoose, ${ }^{42}$ new arrays were ordered when too few women appeared on the original arrays. In $R$. v. N ahdee, ${ }^{43}$ the accused successfully challenged the array because of irregularities in the selection of aboriginal persons, and in R. V. B orn With A Tooth, ${ }^{44}$ the Crown prevailed on a challenge to irregularities in the selection of aboriginal citizens. However, challenges to arrays on the grounds that they did not contain a sufficient proportion of persons of a racial or ethnic group have tended to fail if there were no irregularities in the selection process itself. If the challenge to the array is not made at the start of trial, section 670 of the Criminal Code states that any irregularity in the summoning or empanelling of the jury shall not be grounds for reversing a verdict. ${ }^{45}$ It is not clear how successful an appeal

36. See WATT \& FUERST, supra note 34 , at 1189-95.

37. See GRANGER, supra note 9 , at 332 .

38. Seeid. at 332-40.

39. See id at 81-142; see also TANOVICH ET AL., supra note 9, at 39-57 (discussing the selection of jury lists from the Canadian provinces).

40. See GRANGER, supra note 9, at 149-51.

41. [1972] 23 C.R.N.S. 44 (Ont. County Ct.).

42. [1988] 46 C.C.C.3d 421 (A Ita. C.A.).

43. [1993] 26 C.R.4th 109 (O nt. G en. D iv.).

44. [1993] 81 C.C.C.3d 393 (A Ita. Q ueen's B ench).

45. See Criminal Code, R.S.C., ch. C-46, § 670 (1985) (Can.). 
would be if strong evidence showing deliberate racial or gender biases in selection were produced after a conviction.

Statutory exemptions from jury service do restrict representativeness to some degree. E ach province is responsible for the law on this matter and the statutes differ somewhat across the provinces. The most common exemptions are for legislators, judges and other court employees, lawyers, and police officers, but some provinces also exempt doctors, veterinarians, firefighters, ministers, and law students.

\section{Jury Selection}

The jury selection process in the Bernardo trial is not typical of Canadian jury practice and procedure. In common practice, challenges for cause occur in only a small percentage of criminal trials. M ost often, jurors are selected without any questioning at all. The trial judge may ask the assembled panel of prospective jurors if any of them has health or other problems that would pose a hardship and if anyone has a relationship with the parties or witnesses in the case. The judge may excuse such jurors. The remaining jurors are then randomly selected, and called one by one to face the accused. A this point, the Crown prosecutor and defense lawyer may exercise one of the peremptory challenges that each side is allotted. However, since no other information is available, except in some provinces the juror's occupation, the decision on a peremptory is made solely on the basis of observable physical characteristics and demeanor of the juror. ${ }^{47}$

The legal presumption behind this practice, as enunciated in a leading case on jury law, R. v. H ubbert, is that a juror will "perform his duties in accordance with his oath" and render a verdict with an impartial mind. ${ }^{48} \mathrm{H}$ ubbert discussed additional factors that bolster this presumption. The jury is composed of twelve persons who will deliberate and cancel any individual biases that exist. A dditionally, the judge's instructions to the jury will have a salutary effect by reminding the jurors that they have a solemn duty to be fair and impartial. ${ }^{49}$

$\mathrm{H}$ ubbert recognized the utility of the challenge for cause process in some cases, but specifically expressed the view that Canadian jury selection procedures should not develop along A merican lines. ${ }^{50} \mathrm{H}$ ubbert was decided in 1975 , but the concern about "A mericanizing" the Canadian jury continues to be expressed by members of the judiciary today ${ }^{51}$ as a consequence of a number of decisions that have liberalized the standards under which challenges for cause

46. See GRANGER, supra note 9, at 83-142.

47. It is known, from the author's professional knowledge from interviews with judges, defense lawyers, and Crown attorneys, that the Crown frequently does search the list to determine if any jurors have a criminal record.

48. [1975] 29 C.C.C.2d 279 (O nt. C.A.).

49. See id. at 296.

50. See id. at 291.

51. See D agenais v. Canadian Broad. Corp. [1994] 3 S.C.R. 835, 839 (Can.); R. v. W illiams [1994] 30 C.R.4th 277, 283-85 (B.C.S.C.). 
should be allowed and the types of prejudices that have been legally recognized. ${ }^{52}$ This article addresses this issue in some detail, but first it is important to discuss how Canadian law attempts to prevent certain types of prejudices from arising in the first place.

\section{B alancing Free Press and Fair Trial}

The B ernardo case introduced the delicate balancing act that the Canadian legal system attempts to maintain between the values of a free press and a fair trial.

This balancing involves the controls that the judiciary may place on the mass media to prevent pretrial publicity. England, with its severe contempt of court laws for those reporting court proceedings, emphasizes the value of fair trial over free press; ${ }^{53}$ the U nited States, with Nebraska Press A ssociation v. Stuart $^{54}$ and related cases, emphasizes the value of free press over fair trial. In contrast, Canada attempts to balance the two competing values. Section $11(d)$ of the Charter guarantees an accused the right "to be presumed innocent until proven guilty according to law in a fair and public hearing by an independent and impartial tribunal," and section 2(b) provides for "freedom of the press and other media of communication." 55 The Criminal Code also declares the right to a proceeding in open court. ${ }^{56}$ However, two sections of the Code place limits on these rights. Section 537 provides the judge with the power to exclude everyone but the prosecutor, the accused, and his counsel from the preliminary inquiry, ordinarily held for indictable offenses. ${ }^{57}$ Section 486 of the Code confers the judge with authority to ban the public and press from all or part of criminal trial proceedings if it is in the interest of public morals, the maintenance of order, or the proper administration of justice. ${ }^{58}$ The apparent contradiction between these sections of the Code and the $C$ harter guarantees are reconciled by section 1 of the Charter, which declares that the rights and freedoms are not absolute: "reasonable limits" may be "prescribed by law as can be demonstrably justified in a free and democratic society." ${ }^{59}$

In addition, section 539(1) of the Criminal Code provides that the accused person has the right to ask for an order banning publication of the content of the proceedings until the charges are dropped or the trial is ended. ${ }^{60}$ The motion must be granted; the judge has no discretion. (The fact that the prelimi-

\footnotetext{
52. See R. v. Sherratt [1991] 1 S.C.R. 509 (Can.); R. v. Parks [1993] 24 C.R .4th 81 (O nt. C.A .).

53. See J A MES Gobert, J UStICE, DemoCRACY, AND THE JURY (1997); S.H. Bailey, The Contempt of Court A ct 1981, 45 M OD. L. REV. 301 (1982); Clive Walker et al., The Reporting of Crown Court Proceedings and the Contempt of Court A ct 1981, 55 M OD. L. R E V. 647 (1992).

54. 427 U .S. 539 (1976).

55. Charter, supra note $14, \S \S 2(b), 11(d)$.

56. See Criminal Code, R.S.C., ch. C-46, § 486 (1985) (Can.).

57. Seeid. $\S 537$.

58. Seeid. § 486 .

59. Charter, supra note $14, \S 1$.

60. See Criminal Code, R.S.C., ch. C-46, § 539(1) (1985) (Can.).
} 
nary inquiry has been held may be reported.) $D$ efendants frequently invoke this right, particularly in cases likely to draw public interest. Consequently, the preliminary inquiry is seldom a source of prejudicial pretrial publicity.

A Ithough the trial judge drew upon common law precedent to ban publication of the content of the Homolka trial proceedings until the termination of the Bernardo trial, his order should be viewed in the context of the general philosophy of the Criminal Code and the Charter, that is, to balance free expression with the right of the accused to a fair trial. The philosophy was also reflected in the Bernardo trial with respect to the judge's decision to prohibit both the public and the press from viewing the videotapes that were shown to the jury. Canadian trial practice does not allow sidebar conferences; the jury is removed from the courtroom for all legal arguments. ${ }^{61}$ The Code proscribes publication of anything said in the absence of the jury until the jury retires to consider its verdict, at which time sequestration is mandatory. ${ }^{62}$ The ban does not apply if the jury is sequestered during the whole trial, but sequestration is extremely rare. ${ }^{63}$

T wo other matters bear on the control of pretrial prejudice. The first is that cameras are not permitted in Canadian courtrooms. ${ }^{64}$ This inhibits inflammatory publicity in sensational cases like B ernardo. The second is that section 649 of the Criminal Code prohibits jurors from ever disclosing anything about their deliberations under threat of a summary conviction that could result in a maximum sentence of six months imprisonment and a fine of up to $\$ 5,000 .{ }^{65}$ This law, passed in 1972, has the effect of curtailing improper juror motivation. Thus, the jurors in the Bernardo case were not tempted to lie about their lack of impartiality in anticipation of a lucrative contract with a tabloid newspaper or a book publisher at the trial's end. Fame and financial gain are not motives for Canadian jurors.

The attempt to balance competing values of fair trial and free press has met some difficult challenges in the face of R oyal commissions of inquiry and mass media saturation, and several of these cases merit further comment. Canadian political culture often encourages the use of formal public inquiries in important matters that affect the public interest. In 1995, the government of Nova Scotia ordered an inquiry into a fatal underground explosion in the Westray Coal M ine and granted its commissioner the power to compel testimony of witnesses, including persons who might face criminal charges. The affected witnesses applied for a temporary stay of the public hearings on the ground that the publicity would jeopardize their right to a fair trial. A Ithough the appeal was argued on the ground that the accused would elect a trial by jury, they sub-

\footnotetext{
61. See GRANGER, supra note 9 , at 213 .

62. See Criminal Code, R.S.C., ch. C-46, § 539(1) (1985) (Can.); see also WATT \& FUERST, supra note 34 , at 854-55 (commenting on this section).

63. See GRA NGER, supra note 9 , at 305-07.

64. See D aniel J. Henry, E lectronic Public A ccess to Court: A Proposal for I ts Implementation Today, in THE MEDIA, THE COURTSAND THE CHARTER, supra note 9, at 441.

65. See Criminal Code, R.S.C., ch. C-46, § 649 (1985) (Can.).
} 
sequently elected trial by judge alone, thereby rendering the issue moot. $\mathrm{Nev}$ ertheless, in Phillips v. N ova Scotia, ${ }^{66}$ the Supreme Court addressed the problem of pretrial publicity generated by public inquiries. The court conceded that publicizing evidence might "irreparably" prejudice jurors, but it emphasized the importance of public interest in the inquiry and placed the burden of proof on the accused to demonstrate the link between publicity and harm. In the decision, the Court stated:

The objective of finding 12 jurors who know nothing of the facts of a highlypublicized case, is today, patently unrealistic.... [I ]mpartiality cannot be equated with ignorance of all facts of the case. ... [I ]n order to hold a fair trial it must be possible to find jurors who, although familiar with the case, are able to discard any previously formed opinions and to embark upon their duties armed with both an assumption that the accused is innocent until proven otherwise, and a willingness to determine liability based solely on the evidence presented at trial. ${ }^{67}$

Phillips asserted that any remedy must be weighed against existing procedural safeguards relating to jury prejudice (such as judicial instructions and challenges for cause). ${ }^{68}$ M oreover, $\mathrm{P}$ hillips sanctioned temporary publication bans of harmful testimony or the conclusions of the inquiry until completion of the criminal proceedings. ${ }^{69}$

R. v. Kenny ${ }^{70}$ and R. v. Burke ${ }^{71}$ also involved a 1989 public inquiry involving charges of obstruction of justice in the investigation of rampant sexual assaults on boys in the $\mathrm{Mt}$. Cashel Orphanage in N ewfoundland by numerous members of the Christian B rothers, a Catholic religious order, who were in charge of the institution. D espite defense motions to delay the inquiry until after the trials of the accused or at least to place a ban on publication, the hearing took place and was covered live on television. The testimony was very graphic about what occurred and who was involved. ${ }^{72}$ The problem was exacerbated by statements prejudicial to the accused by public officials. A dditionally, the convictions of the first members to stand trial received extensive media coverage in Newfoundland and across Canada. K enny, one of the accused, moved for a permanent stay of proceedings on the ground of prejudicial pretrial publicity. The trial judge, while conceding that the publicity had prejudiced the community, nevertheless concluded that the risk of bias could be neutralized by jury selection procedures and judicial instructions, and denied the motion. Kenny then elected trial by judge alone and was convicted. ${ }^{73} \mathrm{H}$ is appeal of the denial of the

66. [1995] 2 S.C.R. 97 (Can.).

67. Id. at 168.

68. Seeid. at 169 .

69. Seeid.

70. [1996] 108 C.C.C.3d 349 (N fld. C.A.).

71. [1994] 8 C.C.C.3d 257 (N fld. C.A.).

72. See J ames R.P. O gloff \& N eil Vidmar, The Impact of Pretrial Publicity on J urors: A Study to Compare the Relative E ffects of Television and Print Media in a Child Sex A buse Case, 18 LAW \& HUM. BEHAV. 507 (1994) (describing the testimony that appeared on television as well as a summary of other background material about the case).

73. See K enny [1996] 108 C.C.C.3d at 349. 
motion to stay was decided by the Supreme Court after Phillips and after Burke.

A nother case involving the balance of a fair trial and a free press was $D$ agenais v. Canadian B roadcasting Corp. ${ }^{74}$ Former and present members of a Catholic religious order who ran an O ntario training school were charged with multiple counts of sexual and physical abuse of young boys who were in their care. A s their trial date approached, their defense lawyers applied for an injunction preventing the Canadian B roadcasting Company from airing a television mini-series program, The Boys of St. Vincent, a fictional account based upon N ewfoundland's M t. Cashel Orphanage cases. R elying on common law authority, the trial judge granted a nationwide injunction on the airing of the $C B C$ series until after the $O$ ntario trials were finished. The $O$ ntario Court of A ppeal upheld the injunction but limited its scope to O ntario and the city of M ontreal. ${ }^{75}$ U pon further appeal, the Supreme Court applied a balancing test under section 1 of the Charter and quashed the injunction. ${ }^{76}$ The Dagenais decision did not absolutely curb common law judicial authority on publication bans, but it enunciated guidelines limiting the scope of such bans and requiring the weighing of potential harms to free expression against some combination of alternative remedial measures, such as adjourning trials, changing venues, sequestering jurors, allowing challenges for cause, and providing strong judicial direction to the jury. The decision was based on a balancing of the salutary effects of a publication ban on the fairness of the trial against the deleterious effects delaying free expression guaranteed by section 2 of the Charter. In fact, $D$ agenais asserted that, unlike the A merican model of a clash between free press and fair trial, section 1 of the Charter requires a balancing of values. It also noted that freedom of expression and the accused's right to a fair trial are not always in conflict, such as when public scrutiny of the court process may protect the fairness of trials. Finally, it noted that publication bans can also protect the privacy of members affected by the trial and other interests.

Note that in B ernardo, Phillips, and Dagenais, the injunctions involved delay, not permanent bans, on media publication or airing of stories. Moreover, Canadian law provides no proscription of news stories developed from sources independent of court hearings. The H omolka hearing's status as a "trial" was also ambiguous, and the ban on publication to protect the Bernardo trial might not have prevailed if $\mathrm{H}$ omolka's guilty plea and sentencing had occurred before the jury trial. A s it was, the media engaged in much commentary regarding the "Ieniency" of her sentence before and during Bernardo's trial, even though such commentary could taint public opinion. Finally, it appears that in recent years, the Supreme Court of Canada has increasingly relied on confidence in "existing procedural safeguards" against jury prejudice in the face of media re-

\footnotetext{
74. [1994] 3 S.C.R. 835 (Can.).

75. See id. at 836 .

76. Seeid.
} 
porting. ${ }^{77}$ This possibly results from the greater use of such procedural devices as the challenge for cause, and the need to allow free expression under the Charter. $^{78}$ Those matters are discussed in the next part of this article, but the important point is that the Canadian Supreme Court appears to be engaging in a pragmatic search for a middle ground between the $E$ nglish and A merican systems regarding the free press/fair trial issue.

\section{III}

\section{Pretrial Prejudice and Procedural Remedies}

Despite the presumption that jurors will follow their oath, and despite measures intended to prevent or minimize tainting of jurors by the mass media, Canadian law and practice recognize that some of the laypersons called to serve as jurors may not have impartial minds regarding the guilt or innocence of the accused. Sometimes this is because the measures have proven ineffective and sometimes this is because, as described below, the sources of potential prejudice arise from sources other than mass media. A number of remedies intended to constrain and guide the laypersons who form the jury to the rational purposes of the law are provided. D uring the 1990s, the courts have shifted the emphasis placed on these remedies, but not without strong controversy amongst the judiciary, the Crown, and the defense bar. B efore turning to these issues, a brief discussion of legal prejudice, or partiality, is useful because it sheds light on the recent developments in case law.

\section{A. Forms of Prejudice}

For purposes of conceptual analysis, potential juror prejudice may be divided into four types. ${ }^{79}$ Interest prejudice, sometimes also called manifest or "obvious" prejudice, ${ }^{80}$ involves jurors who may have a direct stake in the trial outcome or at least whose presence would appear to be unfair to one of the parties. Thus, persons who have a direct familial, social, or economic relationship with the accused, the victim, or witnesses, or who might be positively or adversely affected by the outcome of the trial would be classified as having an interest prejudice. Interest prejudice may be inferred on the basis of the juror's connection to the trial without a specific assessment of his or her attitudes.

Specific prejudice exists when the juror holds attitudes or beliefs about the specific case at trial that would prevent that person from deciding guilt or innocence with an impartial mind. These attitudes and beliefs could arise from per-

77. See Phillips v. N ova Scotia [1995] 2 S.C.R. 97, 169 (C an.).

78. In 1998, new controversy developed over the frequency and extent to which judges are prone to grant bans on publicity as a result of some controversial cases, but the matter has not been resolved at the level of appeal courts. See B rian B ergman, To Gag or N ot to G ag, M A CLEA N's, O ct. 19, 1998, at 81.

79. See Neil Vidmar, Pretrial Prejudice in Canada: A Comparative Perspective on the Criminal J ury, 79 J U DICA TURE 249, 252 (1996).

80. R. v. Sherratt [1991] 1 S.C.R. 509, 534 (Can.). 
sonal knowledge about the case, publicity from the mass media, or informal discussion and rumor about the case among members of the community.

G eneric, or general, prejudice involves the transferring of attitudes or beliefs about the case or its participants as a result of the juror's preexisting beliefs, or stereotyping, of the defendant, the victim/complainant, or the crime itself, such that the case is not decided impartially. ${ }^{81}$ A s contrasted to specific prejudice, knowledge about the case or the particular identities of the trial participants is immaterial. R ather, it is the perceived characteristics of the parties or the crime itself that causes the juror to code the case as falling within a class or category of cases in which the juror is inclined to lower the burden of proof regarding guilt or to evaluate the evidence in a biased manner. R acial or ethnic prejudice is one of the oldest recognized forms of generic prejudice. The person is judged on the basis of his or her identity as a member of a group, rather than on the specific facts brought out in the trial evidence. There are research findings indicating that the mere existence of charges of child sex abuse causes some persons to infer that the accused is likely guilty. G eneric prejudice is not mere abhorrence of the crime itself, but rather the inability to fairly decide guilt on the basis of the trial evidence.

Finally, conformity prejudice exists when the juror perceives that there is such strong community interest in a particular outcome of a trial that he or she is influenced in reaching a verdict by the community's feelings rather than an impartial personal evaluation of the trial evidence.

While most psychologists would recognize all four of the above categories as sources of potential prejudice, the central issues in jury law are if, when, and under which circumstances a court will recognize them as legally cognizable sources of partiality and which remedies to apply if the prejudice is acknowledged. A lthough not under the specific terminology applied here, all common law jury systems appear to recognize interest, specific, and conformity prejudice. $^{82}$ However, only a small number of common law jury systems appear to recognize forms of generic prejudice per se. At the end of the middle ages, England appears to have recognized forms of generic prejudice with its provisions for a jury de medietate linguae, where foreigners involved in civil or criminal litigation were entitled to a jury composed of six of their countrymen and six Englishmen. ${ }^{83}$ United States case law and practice recognize racial and other generic prejudices.

Canadian case law provides numerous attempts at definitions of juror partiality, the most general of which is not being "indifferent between the Queen

81. For additional elaboration of generic prejudice, see Neil Vidmar, G eneric Prejudice and the Presumption of G uilt in Sex A buse Trials, 21 LA W \& HUM. BEHA V. 5 (1997).

82. See GERTNER \& MIZNER, supra note 8, at 3-9 to 3-17; G ary K napp, A nnotation, Scope of Voir Dire Examination, 114 L.E d.2d 763 (1995).

83. See, e.g., Marianne Constable, The law of the Other: The Mixed Jury and CHANGING CONCEPTIONS OF CITIZENSHIP, LAW, AND KNOWLEDGE (1994) (discussing early English practice). 
and the accused." ${ }^{84}$ H owever, in the leading case, R. v. Parks, ${ }^{85}$ decided by the O ntario Court of A ppeal (and subsequently refused leave to appeal by the Supreme Court ${ }^{86}$ ) the definition was articulated in precise form:

Partiality has both an attitudinal and behavioural component. It refers to one who has certain preconceived biases, and who will allow those biases to affect his or her verdict despite the trial safeguards designed to prevent reliance on those biases. A partial juror is one who is biased and will discriminate against one of the parties to the litigation based on that bias. ${ }^{87}$

This definition is broad enough to encompass all four types of prejudice described above. A nd, indeed, the very recent Supreme Court case of R. v. Williams ${ }^{88}$ recognized all four types of prejudice, though without coming to grips with limits to the scope of generic prejudice. However, as will be described below, the issue of generic prejudice has been a significant source of controversy within the Canadian legal system.

\section{B. Remedies for Prejudice}

The Criminal Code and Canadian case law provide a number of remedies for juror prejudices, or partiality. In addition to adjournments of proceedings, these are judicial instructions, peremptory challenges, challenges for cause, changes of venue, and trial by judge alone. ${ }^{89}$

1. Judicial Instructions. As already discussed, Canadian courts have expressed a strong belief in the power of judicial instructions to guide jurors to be fair and impartial. This presumption was stated in $\mathrm{H}$ ubbert, but enunciated even more strongly in R. v. Corbett, ${ }^{90}$ a case involving the issue of whether prior convictions of the accused could be introduced in evidence bearing on character if the accused chose to testify. R ejecting social science research that indicated that jurors were influenced by knowledge of criminal records, Corbett asserted confidence in the experience of trial judges that firm instructions from the judge caused juries to perform their duties according to the law. ${ }^{91}$ The reasoning of Corbett was specifically applied to pretrial publicity in Dagenais, with the caveat that judicial instructions were not invariably efficacious in eliminating the effects of pretrial publicity. ${ }^{92}$

84. R. v. Hubbert [1995] 29 C.C.C.2d 279, 286 (O nt. C.A .).

85. [1993] 24 C.R.4th 81 (O nt. C.A.).

86. [1994] 1 S.C.R. x (Can.).

87. Parks [1993] 24 C.R.4th at 93.

88. [1998] 159 D.L.R.4th 493 (Can.).

89. See D agenais v. Canadian Broad. Corp. [1994] 3 S.C.R .835 (Can.). D agenais makes reference to the remedy of adjournment of the trial until the effects of publicity have abated. A djournments are authorized under $\S 645$ of the Criminal C ode and are under the discretion of the trial judge. H owever, the case law on adjournments for pretrial publicity is sparse and largely noncontroversial. I will not discuss it further here.

90. [1988] 1 S.C.R . 670, 695 (Can.).

91. Seeid.

92. See D agenais [1994] 3 S.C.R . at 885. 
2. Peremptory Challenges and Stand-A sides. Following the traditions of common law and the underlying rationale, the peremptory challenge remains a part of Canadian law. ${ }^{93}$ In cases involving treason or murder, both the prosecutor and the accused are entitled to twenty peremptories. For offenses in which the accused may be sentenced to more than five years in prison, both sides have twelve peremptory challenges, and for other offenses each side has four. In joint trials, each co-accused has the same number of peremptory challenges as if he or she were tried alone. The purposes of the peremptory challenge are recognized as the same as those articulated by Blackstone, who has been favorably quoted on the issue. ${ }^{94}$ It provides a perception of trial fairness to the accused to be able to eliminate persons with whom the accused has an uncomfortable feeling, no matter what the basis behind the impression of the prospective juror. A dditionally, in instances in which there is suspicion about the venireman's professed indifference to the matters at the bar, but there are not sufficient grounds to eliminate the person for cause, the peremptory provides a mechanism to do so.

Prior to 1992, the Crown also had the right to "stand-aside" (also called "stand-by") up to forty-eight jurors with no reasons given. The stand-aside procedure was adopted from English practice in the Criminal Code of 1892. O riginally the number of stand-asides was unlimited, but in 1917 the number was reduced to forty-eight. ${ }^{95}$ The rationale for the stand-aside was the same as in English law, namely to allow the Crown to eliminate jurors deemed unfit or hostile to the Crown. H owever, in 1992 in R. v. Bain, the Supreme Court concluded that stand-asides violated the Charter because a reasonable person would conclude that it provided the Crown with an unfair advantage over the accused. $^{96}$ Subsequently, Parliament amended the Criminal Code and abolished stand-asides, but it simultaneously gave the Crown the same number of peremptories as the accused. ${ }^{97}$

W ith the exception of the stand-aside, peremptory challenges have not been controversial as they have been in England or the U nited States. ${ }^{98}$ There are probably a number of reasons, including such factors as tighter controls in Canada on the trial process, lack of extensive pretrial questioning of jurors, rarity bordering on a near absence of in-court jury selection experts, and the fact that legal issues of jury representativeness per se are minimized by case law and the Criminal Code. However, R. v. Biddle ${ }^{99}$ deserves brief comment because it can

93. See Criminal Code, R.S.C., ch. C-46, § 634 (1985) (Can.).

94. See R. v. Bain [1992] 1 S.C.R. 91, 152 (Can.) (quoting 4 WILLIAM BLACKSTONE, CoMMENTARIES *353).

95. Seeid. at 109.

96. Seeid. at 105.

97. See GRA NGER, supra note 9, at 144-45. When multiple defendants are involved in a trial, each has the allotted number of peremptories, but the Crown's number of peremptories are not increased. See Criminal Code, R.S.C., ch. C-46, § 634 (1985) (Can.).

98. See L loyd-B ostock \& Thomas, supra note 28 , at 23-27.

99. [1995] 1 S.C.R. 761 (Can.). 
be compared with the U.S. case of J.E.B. v. A labama, ${ }^{100}$ which forbids the use of gender-based peremptories. Biddle was convicted by an all-female jury of two 1986 rapes, largely on the basis of contested eyewitness identification evidence. The Crown had exercised its stand-by privileges to eliminate male jurors. Biddle's conviction was overturned on other grounds and since Bain had subsequently ruled the stand-by unconstitutional, the question of the all-female jury was only academic. However, in a concurring opinion, one justice commented that "[w]hile representativeness is not an essential quality on the jury," it is a "characteristic which furthers the perception of impartiality." ${ }^{101}$ Consequently, the prosecution's "apparent attempt" to modify the jury's composition undermined jury impartiality. ${ }^{102} \mathrm{H}$ owever, in opinions that concurred with overturning the conviction, two justices disagreed with this assessment, with one stating:

I agree that a jury must be impartial and competent. But, with respect, the law has never suggested that a jury must be representative. For hundreds of years, juries in this country were composed entirely of men. A re we to say that all these juries were for that reason partial and incompetent? ${ }^{103}$

In short, it is not clear how the Supreme Court would rule in a case in which one side exercised its peremptories to systematically eliminate jurors on the basis of gender or race.

3. Challenges for Cause. In contrast to peremptory challenges, challenges for cause have evoked considerable legal controversy within the past decade. ${ }^{104}$ They have occurred with greater frequency than in the past, and both trial and appellate judges have disagreed on the scope of permissible grounds of these challenges, as well as on the scope of the permissible questions. ${ }^{105}$ Courts in O ntario have allowed challenges for cause with greater frequency than in other provinces. Judges in other provinces have either actively resisted challenges for cause, or the matter has seldom arisen, at least in reported case law. ${ }^{106}$

A s a first matter, attention needs to be drawn to the fact, alluded to earlier, that the Canadian judge does not have the power to dismiss individual jurors from the array on the grounds of prejudice. ${ }^{107}$ The judge is allowed to dismiss some persons if he or she determines in open court that the juror has a personal interest in the matter to be tried, has a relationship with the judge or any of the parties or witnesses to the suit, or would suffer personal hardship or suffers

100. J.E.B. v. A labama ex rel. T.B., 511 U .S. 127 (1994).

101. Biddle[1995] 1 S.C.R . at 788.

102. Id.

103. Id.

104. See A ustin M. Cooper, The A BC s of Challenge for Cause in J ury Trials: To Challenge or N ot to Challenge and What to A sk If Y ou G et It, 37 CRIM. L.Q. 62 (1994); David M. Tanovich, Rethinking J ury Selection: Challenges for Cause and Peremptory Challenges, [1994] 30 C.R.4th 310; D avid Paciocco, Challenges for Cause: Cameron and Sexual O ffence Cases (A pr. 1995) (unpublished manuscript) (on file with author); Steven Skurka, Challenge for Cause: Q uestions A llowed Since R. v. Parks (Nov. 11, 1994) (unpublished manuscript) (on file with author).

105. See GRANGER, supra note 9, at 158-88.

106. Seeid.

107. Seeid. at 187-88; TA NOVICH ET A L., supra note 9, at 81-83, 161. 
from a disability. ${ }^{108}$ H owever, the Code states that two lay triers shall decide the issue of impartiality of a challenged juror. ${ }^{109}$ The challenge process proceeds in the manner described in the Bernardo trial. ${ }^{110}$ T wo laypersons are randomly chosen to serve as a mini-jury to render a verdict on the impartiality of the challenged juror. A fter the first impartial juror is chosen, he or she becomes a trier for the next juror, and the process of selection and trier replacement with a newly selected juror continues until a jury of twelve is selected. O rdinarily, the jury panel is removed from the courtroom for the challenging process on the theory that observing the process may affect their answers. ${ }^{11}$

The trial judge, however, plays a crucial role in determining whether a challenge shall be allowed and the form of the questions that may be put to the jurors. ${ }^{112}$ Since there is a legal presumption that a juror is impartial, the burden of proof for overcoming this presumption lies with the party requesting the challenge. In practice, this is almost always the accused. The standard of proof is low, namely proof of an "air of reality" or a "realistic potential."113 The evidence introduced in support of a challenge has involved newspaper articles, testimony by persons knowledgeable of the community, and expert opinion by social scientists, sometimes buttressed with a public opinion survey designed specifically for the case. ${ }^{114}$ In recent years, a number of judges have taken judicial notice of the existence of forms of prejudice in permitting challenges for cause. A s will be described below, for certain cases where the race of the parties might be an issue, recent case law has asserted that the accused need only present a prima facie case to challenge on grounds of potential racial bias. H owever, even though the standard of proof is low, the costs of producing evidence serves to inhibit requests for challenges for cause in many cases.

The judge is charged with keeping a tight rein on the forms of questions that may be asked of jurors. In response to concerns about "A merican-style" voir dire, $\mathrm{H}$ ubbert asserted that "[C]hallenge for cause is not for the purpose of finding out what kind of juror the person called is likely to be-his personality, beliefs, prejudices, likes or dislikes." ${ }^{115}$ Typically, the questions put to jurors are limited in number, often only one or two, and require only yes or no answers. U sually the questions are written out in advance and approved by the judge. The questions must directly address the juror's state of mind. The lawyer for the side that requests the challenge asks the questions.

In R. v. Parks, the jurors were asked:

108. SeeTANOVICH ET AL., supra note 9, at 77-83.

109. See Criminal Code, R.S.C., ch. C-46, § 640 (1985) (Can.).

110. SeeTANOVICH ET AL., supra note 9, at 151-64.

111. Seeid. at 165.

112. See id. at 84-106.

113. See id. at 95-100.

114. See id. at 137-47; V idmar \& M elnitzer, supra note 10 , at 491-93.

115. R. v. Hubbert [1975] 29 C.C.C.2d 279, 289 (O nt. C.A.). 
A s the judge will tell you, in deciding whether or not the prosecution has proven the charge against an accused a juror must judge the evidence of the witnesses without bias, prejudice or partiality:

(1) In spite of the judge's direction would your ability to judge witnesses without bias, prejudice or partiality be affected by the fact that there are people involved in cocaine and other drugs? ${ }^{[16]}$

(2) Would your ability to judge the evidence in the case without bias, prejudice or partiality be affected by the fact that the person charged is a black Jamaican immigrant and the deceased is a white man? ${ }^{117}$

In R. v. Cameron, the judge allowed the following question:

$\mathrm{A} s \mathrm{H}$ is $\mathrm{H}$ onor will instruct you, in deciding whether or not the prosecution has proven the charge against an accused, a juror must judge the evidence of all the witnesses, both for the Crown and for the defence, without bias, prejudice, or partiality.

In spite of $\mathrm{H}$ is $\mathrm{H}$ onour's direction, would your ability to judge the accused without bias, prejudice or partiality be affected by the fact that he was selling cocaine on the day in question? ${ }^{118}$

Most often, the judge does not allow further exploration of the juror's reasoning behind the answer. The triers make their decision based on the juror's yes or no answer about whether he or she can be fair and impartial. In practice, this process of jury selection typically consumes about two hours of trial time.

In cases involving pretrial publicity, the judge may permit additional questions. In R. v. L esso, ${ }^{119}$ the judge allowed the following questions: H ave you discussed the case with anyone? If yes, have you expressed an opinion about the guilt or innocence of the accused? If no, do you have an opinion as to the guilt or innocence of the accused? If yes, what is that opinion? In a Prince Edward I sland case, R. v. Cameron, ${ }^{120}$ involving a doctor in a small community accused of sexually assaulting his patients, the jurors were asked up to five questions: whether they had been a patient or had some other relationship with the accused; whether they knew and had attitudes or beliefs about trial witnesses that would cause them to give the testimony of those witnesses more or less credibility than other witnesses; whether they had discussed and formed an opinion about the case; whether they had strong beliefs about sexual assault that would prevent them from being impartial; and whether they had any other beliefs about the case or about sexual assault in general that would prevent them from being impartial.

In most cases, judges have held that it is inappropriate to ask jurors whether they are members of a particular race or class of society, about their personal experiences such as whether the juror or a member of the juror's family has been the victim of an offense, and what the prospective juror's beliefs are, in-

116. The judge was ruled in error for having permitted this question. See [1993] 24 C.R.4th 81, 88 (O nt. C.A.).

117. Id.

118. [1995] 96 C.C.C.3d 346, 348 (O nt. C.A.).

119. [1973] 23 C.R.N.S.179, 187-91 (O nt. H.C.J.).

120. No. G SC-13385 (P.E.I.S.C. (Trial D iv.) A pr. 15, 1994). 
cluding whether they belong to any groups, such as a victim support group, or fraternize with particular ethnic or racial groups. ${ }^{121}$

The limited questioning allowed in challenges for cause renders it an imperfect device for ferreting out prejudice since the juror might not understand the question and typically is required to answer only yes or no. However, in actual experience with challenges for cause, a number of jurors do affirm that they are not impartial and are rejected by the triers. ${ }^{122}$ A dditionally, the process of asking the juror if he or she can be impartial is believed to reinforce the judge's admonition at trial of the need to be fair and impartial. ${ }^{123}$ Thus, Canadian jury law may again be seen as seeking a middle ground between the extensive, intrusive and occasionally time-consuming A merican voir dire and the near refusal of E nglish law to recognize that some jurors may not be "impartial between the Q ueen and the accused."

The primary controversy regarding challenges for cause has involved forms of generic prejudice. Since the mid-1970s, a number of trial judges in Toronto, O ntario have taken cognizance of the existence of racial prejudice in that city and allowed challenges regarding whether jurors held racial prejudice. ${ }^{124}$ In R. v. Parks, the O ntario Court of A ppeal took judicial notice of the fact that "[a] significant segment of our community holds overtly racist views" and indicated that the black person accused of second-degree murder involving a drug transaction should have had the right to challenge jurors on their impartiality without the need to demonstrate actual prejudice. ${ }^{125}$ The reasoning of the Parks decision was subsequently extended to cases outside of Toronto and to cases involving important witnesses who were members of that minority group. ${ }^{126}$

Subsequently, in British Columbia an aboriginal (Canadian Indian) defendant facing charges of robbery, requested a challenge for cause involving racial bias. In the resulting case of $\mathrm{R}$. v. Williams, both the trial judge ${ }^{127}$ and the $B$ ritish Columbia Court of A ppeal ${ }^{128}$ denied the motion. The judges acknowledged that there was widespread prejudice against aboriginal people in the community, but asserted there was no evidence that there was a nexus between the prejudice and the ability of jurors to decide the case impartially if properly instructed by the trial judge. The B ritish Columbia courts also attempted to dis-

121. See GRANGER, supra note 9, at 181-86; TANOVICH ET AL., supra note 9, at 147-50.

122. See Vidmar \& M elnitzer, supra note 10, at 50; V idmar, supra note 81, tbl.1; Neil V idmar, Social Science and Jury Selection, in LAW SOCIETY OF UPPER CANADA, PSYChOLOGY AND THE LITIGATION PROCESS 100, 125 (1976) (discussing the unreported case of R. v. D oxtator).

123. See R. v. K oh [1998] N os. C25944, C27462, 1998 O nt. C.A . LE XIS 859, *29 (O nt. C.A. D ec. 30, 1998).

124. See V idmar \& M elnitzer, supra note 10 , at 488.

125. [1993] 24 C.R.4th 81, 99 (O nt. C.A.).

126. See R. v. Willis [1994] 90 C.C.C.3d 350 (Ont. C.A .); R. v. M organ [1995] 42 C.R.4th 126 (O nt. Gen. Div.); see also TA NOVICH ET AL., supra note 9, at 110-11 (discussing challenges for cause based on racial bias).

127. [1994] 30 C.R.4th 277 (B.C. Sup. Ct.).

128. [1996] 106 C.C.C.3d 215 (B.C.C.A.). 
tinguish the case from Parks. The case was appealed, and in R. v. Williams, ${ }^{129}$ the Supreme Court in a unanimous nine-zero decision ruled that the challenge should have been allowed and directed a new trial. The Court recognized generic prejudices beyond just racial prejudice and their potential influences on jurors, while still asserting the trial judge's discretion to decide the merits of challenges for cause on a case-by-case basis.

B oth before and after Parks, individual trial judges have allowed challenges for cause bearing on other types of generic prejudice. ${ }^{130}$ These have included prejudices involving other racial groups, homosexuality, HIV status, offenses involving domestic violence, violence against women, elderly persons, and the police, and drug offenses, particularly when the drug charges were intertwined with racial issues. In addition, in a substantial number of O ntario cases, trial judges have allowed challenges in cases involving sexual offenses against children. ${ }^{131}$ D espite a substantial number of documented cases in which jurors admitted to not being impartial when an accused was charged with sexual abuse, ${ }^{132}$ in R. V. B etker, ${ }^{133}$ the O ntario Court of A ppeal ruled that challenges based on this type of offense were inappropriate. The reasoning of the Court involved complicated issues that are beyond the scope of this overview of Canadian law. H owever, following the Supreme Court decision in R. v. Williams, the issue of offense-based challenges has been re-opened and a number of such challenges have been allowed by 0 ntario trial judges. ${ }^{134}$

It is reasonable to conclude that the challenge for cause is a procedural remedy that is in a state of change and development. A Ithough the various appeal court decisions have stated that the law as defined in $\mathrm{Hubbert}$ has not changed, the empirical result in O ntario has been a substantial expansion of the right to challenge for cause, accompanied with a partial retrenchment regarding sexual offense-based challenges. The Parks case and its progeny and the Williams decision are at once a recognition of changing social conditions in Canada and an attempt to provide a remedy to foster the legal goal of a fair trial and public perceptions of fairness. Lawyers and judges in other provinces have been more conservative regarding the use of the challenge for cause, continuing to rely more heavily on the presumption that a juror will be impartial. The Williams decision, however, will surely result in more frequent challenges when the accused is a member of a minority group. ${ }^{135}$ Whether there will be spillover effects regarding other forms of pretrial prejudice or other developments cannot be foretold at the present time.

129. [1998] 159 D.L.R.4th 493 (C an.).

130. See GRANGER, supra note 9, at 178-81; TA NOVICH ET AL., supra note 9, at 115-37.

131. SeeTANOVICH ET AL., supra note 9, at 119-24; V idmar, supra note 81, tbl.1.

132. SeeTANOVICH ET AL., supra note 9, at 119-94; V idmar, supra note 81, tbl.1.

133. [1997] 115 C.C.C.3d 421 (O nt. C.A .).

134. This conclusion is based on personal conversations with Professor $D$ avid Paciocco.

135. In R. v. Koh [1998] Nos. C25944, C27462, 1998 Ont. C.A. LEXIS 859 (O nt. C.A. Dec. 30, 1998), a case involving charges of narcotics trafficking, the O ntario Court of A ppeal stated that racism was not unique or indigenous against blacks and extended to persons of $A$ sian/Chinese origin. K oh expanded the right to challenge elaborated in Parks to accused who are "minorities of colour." 
4. Changes of Venue. The basic rule at common law was that the trial should be heard in the community in which the crime occurred, and that is still the presumption in Canada. However, the Code provides that either the accused or the prosecutor may apply for a change of venue if "it appears expedient to the ends of justice." 136 This could mean convenience to the parties or other matters, but is also interpreted to include situations where substantial segments of the community are believed to be so tainted by pretrial prejudice that a fair trial cannot be held. The standard for moving a trial has been a showing that there is a "fair and reasonable probability of partiality or prejudice." ${ }^{137}$ M ost authority seems to indicate that change of venue is a more extreme remedy than a challenge for cause. ${ }^{138}$

The nature of proof tendered by the applicant is similar to that in a challenge for cause application. It may be documentary evidence, viva voce evidence, or expert testimony. In a number of cases, a basis of the expert's testimony has been a public opinion poll carried out in the relevant community and sometimes in comparison communities. ${ }^{139}$

5. Trial by Judge Alone. Recall that there are some crimes, including murder, in which the Code specifies that the accused must be tried by judge and jury. ${ }^{140}$ The Code indicates that this may be changed to judge alone only with the consent of both the accused and the Crown. ${ }^{141}$ In R. V. M CG regor, ${ }^{142}$ the accused was charged with killing his estranged wife with a cross-bow on the street near the Parliament buildings in Ottawa. The killing occurred on the first anniversary of the mass killings of a number of female engineering students in the City of M ontreal. There was a great deal of publicity about the killing and its relation to the "M ontreal M assacre." The accused chose to plead not guilty by reason of insanity and wished to be tried by judge alone. The Crown would not consent, arguing that a change of venue was the appropriate remedy. Counsel for McG regor introduced survey data through two experts who indicated that there was not only extremely high prejudice in the community but that there was also substantial generic and specific evidence of lack of impartiality toward the insanity defense. H owever, the survey data also indicated that generic prejudice against the insanity defense would likely be substantial in the county to which the Crown proposed moving the trial, thereby raising the possibility that a challenge for cause would be required even if the trial was moved. In addition, defense counsel made other arguments,

136. Criminal Code, R.S.C., ch. C-46, §599 (1985) (Can.).

137. GRANGER, supra note 9 , at 61 .

138. Seeid. at 57-78.

139. See R. v. Theberge [1995] No. 2666-90 1995 Ont. C.A. LEXIS 1206 (O nt. G en. Div. Mar. 16, 1995); Neil V idmar \& J ohn W.T. Judson, The U se of Social Science Data in a Change of Venue A pplication: A Case Study, 59 CA N A DIA N B. R EV. 76 (1981).

140. See Criminal Code, R.S.C., ch. C-46, § 471 (1985) (Can.).

141. Seeid. § 473.

142. [1992] 14 C.R.R.2d 155 (Ont. Gen. Div.); see also TANOVICH ET AL., supra note 9, at 29-32 (discussing the judge versus jury issue). 
such as the need for access to 0 ttawa-based psychiatric consultants during the trial. Relying on section 24(1) of the Charter, which provides for a court to provide a remedy if any accused rights are in jeopardy of being infringed, the court granted trial by judge alone.

\section{IV}

\section{Controls on the Rest of the Trial Process}

The Canadian presumption about jurors following their oath and the tightly restricted questioning process when challenges for cause are allowed needs to be viewed in the context of the whole jury system. Not only does Canadian law attempt to control factors that might engender pretrial prejudice, it also provides for greater control over the jury than does the A merican system. In fact, in this regard, it bears greater similarity to the jury systems of England, A ustralia, and New Zealand.

\section{A. D uties of the Trial J udge}

The Canadian trial judge has limited discretion to summon witnesses who are not called by either the prosecutor or the defense if he or she determines that it is necessary to the "ends of justice." ${ }^{143}$ The exercise of this power does not require the consent of the parties. The power must be used sparingly and is regularly exercised. The judge also has a positive duty to put questions to a witness in order to clarify an obscure answer, a misunderstanding of a question put to the witness, or an omission by legal counsel of a question that the judge believes is relevant to the issues in the case. ${ }^{144}$ It is improper for either the Crown prosecutor or defense counsel to offer any personal opinions about the evidence or for the defense lawyer to invite the jury to ignore the law. ${ }^{145}$

E qually important, after the evidence and final arguments have been given, the trial judge has the positive duty of reviewing the case for the jury. ${ }^{146}$ The judge must impartially, but substantially, review the theories of the prosecution and the defense and the evidence presented by both sides. M oreover, the judge is entitled to express an opinion to the jury about the importance of various pieces of evidence and may even offer an opinion regarding the credibility of a witness. In undertaking this commentary, the judge must make it clear that the jury is not bound to accept her opinion regarding the facts. The judge also has the obligation of raising any questions arising from the evidence that favor the accused even if they were not raised by the accused's legal counsel. The jury also must be instructed on reasonable doubt and the unanimity requirement. The judge may provide the jury with a written description of the different ver-

143. See GRANGER, supra note 9, at 216-19.

144. Seeid.

145. See id. at 221-41.

146. See id. at 243-304. 
dicts open to it but may not ask the jury to particularize the basis of its verdict; only a general verdict is considered to be proper.

Canadian legal thinking regards this judicial guidance to the jury as significant in the mitigation of any prejudices held by members of the jury. This is a large, though implicit, factor in the presumption that jurors will follow their oath to be impartial. It is also important in the belief that even when challenges for cause are allowed, the limitations of the highly circumscribed questioning process are capable of being offset by the intervention and guidance of the judge.

\section{B. Expert E vidence}

The issue of the reliability and utility of expert evidence has engendered concern in $\mathrm{Canada}^{147}$ as it has in the U nited States and other countries. ${ }^{148}$ The concerns have focused around forensic evidence from the natural sciences such as D N A tests, fiber samples, and explosive residue. However, Canada has also seen an increase in testimony involving the behavioral sciences. In R. v. $L$ avalee, ${ }^{149}$ involving a woman accused of killing her partner, the Supreme Court approved the admissibility of testimony about "B attered W oman Syndrome." In other cases, evidence has been tendered about the "Child Sexual A buse A ccommodation Syndrome," reliability of eyewitness identification, and other social science evidence. ${ }^{150}$ Issues have been raised about the validity and reliability of some of the expert evidence and upon its impact on the jury. ${ }^{151}$

R oughly similar to the U.S. cases of D aubert v. M errell D ow Pharmaceuticals, Inc. ${ }^{152}$ and G eneral Electric C 0 . v. J oiner, ${ }^{153}$ in R. v. M ohan ${ }^{154}$ the Supreme Court of Canada enunciated a number of criteria for determining the admissibility of expert evidence. Mohan stated that not only must such evidence be logically related to a fact in issue, it must also meet a threshold of reliability beyond the qualification of the expert. A dditionally, when the testimony engages a novel scientific theory or technique, it should be subject to special scrutiny. M ohan was intended to draw the judge's attention to his or her responsibility to screen expert evidence allowed in court. A $n$ important goal of the M ohan decision was to prevent juries from being influenced by unreliable expert evidence

147. See $P$. B rad Limpert, B eyond the Rule in M ohan: A N ew M odel for A ssessing the R eliability of Scientific Evidence, 54 U. TORONTO FAC. L. REV. 65 (1996); D avid M. Paciocco, Expert Evidence: Where A re We Now? Where A re We Going? (J an. 31, 1998) (unpublished manuscript presented at Canadian Bar A ssociation 1998 Institute of Continuing L egal E ducation) (on file with author).

148. See David Faigman et al., Modern SCIEntific Evidence: The LaW and SCIEnce of EXPERT TESTIM ONY (1997); Sophia I. Gatowski et al., The D iffusion of Scientific Evidence: A Comparative A nalysis of A dmissibility Standards in A ustralia, Canada, E ngland, and the U nited States, and Their I mpact on the Social and Behavioural Sciences, 1996 E X PERT E VIDE N CE 86.

149. [1990] 1 S.C.R. 852 (Can.).

150. See Paciocco, supra note 147 , at 14 .

151. Seeid. at 33.

152. 509 U .S. 579 (1993).

153. 118 S. Ct. 512 (1997).

154. [1994] 2 S.C.R . 9 (Can.). 
while still permitting new and novel evidence if it was relevant. ${ }^{155}$ Subsequently, in R. v. O Iscamp, ${ }^{156}$ testimony about Child Sexual A buse A ccommodation Syndrome was ruled inadmissible and in another case, R. V. M clntosh, ${ }^{157}$ expert evidence bearing on eyewitness reliability was excluded. Q uestions are also being raised about evidence derived from the natural sciences. H owever, as commentators have pointed out, Canadian courts have been inconsistent in applying the M ohan criteria from case to case. ${ }^{158}$ Thus, M ohan set the stage for a control on what juries see and hear, but systematic application of these controls is in a developmental stage.

\section{Crown A ppeal of an A cquittal}

It would be remiss to fail to mention a striking feature of Canadian law. While the Charter gives great weight to the presumption of innocence, the Crown does have a limited right to appeal a jury acquittal. The Code provides that the A ttorney General has the right to appeal a verdict of acquittal or a verdict of not criminally responsible on account of mental disorder. ${ }^{159}$ The grounds for an appeal must involve an issue of law, such as a claim that the jury was not properly instructed on the law. This limitation on double jeopardy requires a thorough review by appeal courts, but on occasion, the Crown has been successful in obtaining a new trial. In 1986, in a highly publicized case, Guy Paul Morin was found not guilty of the murder of nine-year-old Christine J essup. ${ }^{160} \mathrm{H}$ is primary defense was an alibi defense but this was complicated by psychiatric testimony that $M$ orin was suffering from severe schizophrenia such that if he did commit the crime, he would not have appreciated the nature and quality of the act. The Ontario A ttorney General filed an appeal on the grounds that the judge misdirected the jury on reasonable doubt and that it had been improperly instructed about Morin's psychiatric condition. The O ntario Court of A ppeal reversed the verdict and ordered a new trial. ${ }^{161}$ The Supreme Court of Canada upheld the reversal with respect to the reasonable doubt instruction. ${ }^{162}$ In his second trial, the issue of schizophrenia was abandoned but the alibi defense was expanded. D espite new evidence of serious police misbehavior, unreliable witnesses, and demonstration of unreliable forensic conclusions regarding hair and fiber samples, after nine months of trial testimony, the jury found Morin guilty of first-degree murder following a week of deliberations. Morin appealed, but while the appeal was pending DNA evidence that

155. See Paciocco, supra note 147 , at $8-15$.

156. [1994] 35 C.R.4th 37 (O nt. G en. D iv.).

157. [1997] 35 O.R.3d 97 (O nt. C.A.).

158. See L impert, supra note 147 , at 83.

159. See Criminal Code, R .S.C., ch. C-46, § 676 (1985) (Can.).

160. See R. v. Morin [1987] 36 C.C.C.3d 50 (Ont. C.A.). For a synopsis of the M orin case from beginning to end, see J ack K ing, The O rdeal of Guy Paul M orin: Canada Copes with Systemic Injustice, CHAMPION, A ug. 1998, at 8.

161. See R. v. M orin [1988] 2 S.C.R. 345, 351 (Can.).

162. Seeid. at 361. 
had not been available during the first two trials eliminated M orin as the killer and his conviction was set aside. A subsequent public inquiry into justice system failures resulted in the lengthy $1998 \mathrm{~K}$ aufman R eport that made many recommendations regarding criminal procedure and the jury system. ${ }^{163}$ The impact of the Kaufman R eport cannot yet be assessed.

The Morin case follows by more than two decades a change in Canadian law, known as the Morgentaler A mendment, ${ }^{164}$ that had allowed an appeals court to actually substitute a verdict of guilty despite a jury finding of not guilty. The Code now only allows ordering a new trial based on matters of law. ${ }^{165}$ The jury is the sole interpreter of the facts. Nevertheless, even with these restrictions, section 676, as Morin demonstrates, is another judicial constraint on the jury.

\section{Some O ther Constraints}

There are a few other factors bearing on the jury system that deserve brief mention. The rules of lawyer behavior outside the courtroom before, during, and after the trial are in marked contrast to those in the U nited States and more in line with the practice in other common law countries. A lawyer holding press conferences to discuss the evidence, the judge, or anything that could affect the trial or by innuendo bring the administration of justice into disrepute would likely face serious contempt of court charges, censure from colleagues, or, more likely, both. Indeed, the legal culture is such that even a lawyer having no connection to a case would be unlikely to offer highly evaluative commentary to the media about the conduct of the case or the witnesses, as frequently occurs in the $U$ nited States. Partly because of this legal culture and partly because of the severe limitations on the jury selection process, in-court jury trial consultants have rarely been employed. ${ }^{166}$ U nder procedural rules, the Crown is required to disclose its witnesses and evidence in advance of trial, but the defense is not under a similar obligation. ${ }^{167}$ This may help to foster a more constrained atmosphere, especially on the part of defense lawyers. Inside the superior courts, lawyers wear black vests and gowns inherited from E nglish tradition (the wigs are, mercifully, absent) and follow formal rules of decorum. O pposing lawyers sit at a counsel table or stand at a lectern during the trial.

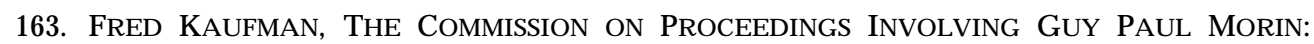
REPORT (1998).

164. M orgentaler, a doctor crusading for abortion rights, was found not guilty of performing an abortion after admitting to all of the elements of the charge but arguing an affirmative defense of necessity. The Q uebec C ourt of A ppeal overturned the jury acquittal and substituted a conviction, based on the trial evidence. However, the public outcry caused Parliament to amend the Criminal Code in 1975 so that while an acquittal can still be appealed, the court can only order a new trial. The details of the trial, appeal, and change in law are described in F.L. MORTON, MORGANTALER V. BOROWSKI: A BORTION, THE CHARTER, AND THE COURTS (1995).

165. See Criminal Code, R.S.C., ch. C-46, § 676 (1985) (Can.).

166. There have been some instances, including several cases in which the present author participated in a low-key manner.

167. See Criminal Code, R.S.C., ch. C-46, § 603 (1985) (Can.); see also WATT \& FUERST, supra note 34 , at 920-26 (discussing disclosure requirements under $\S 603$ ). 
They can approach a witness only with permission of the judge. A ddresses to the jury at the beginning and end of the trial are made from the lectern. ${ }^{168}$ Special deference is given to the judge, who until recent years was always addressed as $Y$ our Lordship or Ladyship, but the prescriptive norms also extend to the forms of address between the lawyers. For instance, even when hotly disputing a legal point, the adversaries frequently refer to their opponent as "my friend." It is not an easily measurable phenomenon, but the atmosphere of the Canadian courtroom surely must have an impact on the jurors.

$\mathrm{V}$

\section{A BORIGINA L PEOPLESAND THE JURY SySTEM}

The I nuit, or E skimo people as they were then known, were first introduced to the Canadian jury system in 1916 in what E dwin K eedy, who was present at the proceedings, aptly labeled a "remarkable murder trial."169 Two priests working among the Inuit people, who were still largely isolated from Western culture, went missing. A fter a long hunt, a party of the Northwest Mounted Police (later the R oyal Canadian M ounted Police) uncovered the fact that two Inuit men, Sinisiak and Uluksak, had killed the priests near the Coppermine $\mathrm{R}$ iver. The two Inuit admitted the acts, and they were transported 2,000 miles south to Edmonton, A Iberta, along with two interpreters and an elderly Inuit who was to be a witness. Sinisiak was appointed legal counsel and the Chief J ustice of the Supreme Court of A Iberta conducted his trial for murder of one of the priests. A lthough the trial took place in summer, in the first stage the two accused were dressed in their native dress, with a tub full of water and ice provided to soak their feet and help them stay cool. Through translators, the Inuit admitted the act of which they were accused, but testified that the priests had abused them and, moreover, created in their minds the belief that the priests were going to kill them. In fact, the Inuit subsequently ate pieces of the priests' liver as a protection against their evil spirits. A the close of the trial, the prosecution contended that the accused killed the priests for their rifles. Defense counsel argued that the Inuit should be judged by the standards of their own culture. The judge instructed the jury that the cultural defense must be rejected. He also told the jury that if Sinisiak was found guilty of murder, he would have no choice, under Canadian law, but to sentence him to death. H owever, the judge also stated that he would recommend clemency, which he was confident would be granted. A fter an hour of deliberation, the jury returned a verdict of not guilty.

168. A Iso noteworthy is the fact that the accused does not sit with his defense counsel. R ather, he must sit in the "prisoner's box" throughout the trial. This rule applies even to the accused who are free on their own recognizance. However, in the light of the Kaufman Report, this practice has been changed in O ntario. See K ing, supra note 160.

169. Edwin R. Keedy, A Remarkable M urder Trial: R ex v. Sinnisiak, 100 U. PA . L. R E V. 48 (1951). For additional discussion of the incident upon which the charges were brought, see ROGER BULIARD, I NUK (1951); RICHARD FINNIE, THE LURE OF THE NORTH (1940). 
The story did not end in Edmonton. Within six days, the accused were moved 200 miles south to Calgary, and both Inuit were tried for the death of the second priest. A fter forty-five minutes of deliberation, the jury returned a verdict of guilty but with the strongest recommendation of mercy. B oth men were sentenced to death by hanging, as required by law, but the I nuit were told that the sentence was deferred until the "Big Chief far away" could review it. On A ugust 19, 1916, the death sentence was commuted to life in prison, and they were returned to the A rctic under custody of the M ounted Police and held first at Herschel I sland and then at G reat Slave Lake. In 1919, the two were released from custody and returned to their people. However, the order of release contained the requirement that they make known to others that:

E skimos live and are governed under a system of law ... with equality as against both white man, Indian and Eskimo .... [W ] hile ... these prisoners have been visited by a dispensation of mercy whereby their lives have been spared ... these reasons are not likely to prevail on another occasion, either for them or for any other E skimo, seeing that the proceedings in the present case have served to inform them of their responsibilities, and that they are solemnly charged with their duty to serve God and honour the $\mathrm{K}$ ing and carefully to observe his laws. ${ }^{170}$

Rex v. Sinisiak serves as a seminal event in attempts to establish the rule of law for aboriginal peoples living in Canada's Northern territories, and some of its themes exist in modern attempts to provide and legitimate law among the Inuit and Indian tribal peoples living in these isolated areas. The jury system is one part of the story. ${ }^{171}$ These territories cover almost three and a half million square kilometers, covering four time zones, with a total population of under 60,000 persons. The sixty-five communities in this area range from a population of eleven to about 14,000 persons, with an average population of approximately 500 residents; in the smaller communities, the majority are aboriginals. There are four major ethnic groups: I nuit (thirty-seven percent of population), D ene (sixteen percent), M etis (seven percent), and "nonnatives" (thirty-nine percent). N ine different languages are spoken, and some dialects are so distinct that peoples speaking the same language cannot easily understand one another. R eflecting social problems that are similar to those experienced by aboriginal peoples all over the world who come in contact with modern culture, the majority of charged crimes involve native accused.

In the first half of this century, the problems of isolation and sparse populations resulted in few jury trials. R ather, cases tended to be tried by a judge or magistrate. However, with the establishment of the Territorial Court of the Northwest Territories in 1955, accused persons have increasingly exercised the right to jury trial. In the first fourteen years, there was an average of five trials

170. K eedy, supra note 169 , at 67 .

171. Except where otherwise noted, this discussion about the jury system is based upon Christopher Gora, J ury Trials in the Small Communities of the Northwest Territories, 13 W INDSOR Y.B. A CCESS J UST. 156 (1993). 
per year. ${ }^{172}$ The Criminal Code provided for six-person juries in the N orthwest Territories because of the sparseness of population, and until 1965, women were prohibited from serving. A dditionally, an eligibility requirement for service was an ability to speak English. In consequence, between 1955 and 1968, despite the fact that aboriginal peoples were the accused in fifty-five percent of the cases, aboriginals served on only twenty-seven of the sixty-six jury trials and typically as only one of the six members. ${ }^{17}$

In 1965, women were declared eligible to serve on juries, and in 1985 the six- person jury was declared unconstitutional. ${ }^{174}$ In 1988, an amendment to the J ury A ct permitted unilingual jurors. ${ }^{175}$ B etween 1987 and 1991, the latest date for which figures are available, an average of forty-seven jury trials took place per year. ${ }^{176}$

Christopher Gora conducted formal interviews with judges, lawyers, and other persons connected to the court process that revealed a number of problems with the implementation of jury trials. ${ }^{177}$ While every effort is made to keep the trial in the community in which the offense occurred, major problems have arisen in this regard. Sometimes the community is too small to obtain a jury, particularly when many of its members are related to the victim or the accused. Linguistic problems continue to be a source of difficulty because of the lack of trained interpreters. In addition, local political struggles between families and ruling cliques can prevent the formation of a jury in that location. Thus, a change of venue is required, bringing additional problems regarding preparation of the case and accessibility of witnesses. M any of G ora's respondents also noted a substantial trend toward acquittals, especially in comparison to trials before a judge alone. ${ }^{178}$ A dditionally, there appears to be a greater reluctance to serve on juries than elsewhere in Canada. B oth the acquittal rates and the reluctance to serve may reflect unwillingness to pass judgment on one's neighbor. However, it also appears to reflect a preference for community values and traditional cultural ways of handling deviance that are in conflict with the legal values and processes of the broader Canadian society.

Gora discussed a number of potential reforms that might ease the difficulties of jury trial in the Canadian N orth. ${ }^{179}$ These include simplifying the charge to make the language more accessible to the jurors and altering the configura-

172. See W.G. M orrow, A Survey of J ury V erdicts in the Northwest Territories, 8 A LTA L. REV. 50, 54-58 (1970); see also J A CK SISSONS, J UDGE OF THE FAR NORTH 181-86 (1968) (discussing the legal system in the Northwest Territories).

173. There were two all-native juries. See M orrow, supra note 172, at 56-57.

174. See R. v. Punch [1985] 22 C.C.C.3d 289 (N.W.T.S.C.).

175. See G ora, supra note 171 , at 162 . U nilingual jurors are provided with translators. Gora noted that the issue of translators attending the actual jury deliberations had not yet arisen. See id. at 167.

176. Seeid. at 170 .

177. See id. at 170-74.

178. This problem was also raised during informal interviews that I undertook in Baker Lake, an Inuit community of about 1,400 persons, in the summer of 1997.

179. See G ora, supra note 171 , at $174-80$. 
tion of the court ${ }^{180}$ to make it more similar to traditional community forums, allowing the community to select the jury pool, and allowing community input into sentencing. Nevertheless, in some respects the essential problems of compatibility of jury trial with the culture and values of aboriginal peoples reflected in R. v. Sinisiak remain, even as these peoples obtain greater exposure to the rest of Canada. ${ }^{181}$

\section{VI}

\section{CONCLUSION}

The Canadian jury system is at once conservative and progressive. It exhibits conservative elements of an earlier age regarding judicial control over the trial process. On the other hand, there are trends in its continuing evolution that attempt to take into account the influence of modern mass media on the fairness of trial, and potential racism resulting from changes in Canada's demographic profile. The recognition that the presumption of impartiality may not always hold even when reinforced with strong judicial instructions involves an implicit recognition of twentieth century psychological understanding of human behavior. Concern about the legitimacy of the jury system in the eyes of minority groups and the small steps that have been taken to increase the actual and perceived fairness are another indication of these progressive trends. This is not to say that the system is ideal. The balancing between competing values and policies has required compromises of substance and process. The developments in Canadian case law also help to illustrate the need to view the jury system in the context of the broader legal and social systems in which it is embedded. The effectiveness of the jury system for the demographic, social, and cultural conditions of Canada's arctic and subarctic regions can be debated. $\mathrm{N}$ evertheless, as a whole, the criminal jury remains a robust institution in the scheme of Canadian life and law.

\footnotetext{
180. Having no formal courthouse, trials in smaller communities take place in hotels, community centers, or schools. The temporary spatial designs, however, are made similar to more traditional court settings.

181. On A pril 1, 1999, the Northwest Territories were divided into two regions with an evolving mandate for self-governance in many areas of community life. The effects of these changes on the jury system cannot be foretold at this time.
} 